\title{
Optimization algorithm for number and wells placement
}

\author{
Algorytm optymalizacji liczby i położenia odwiertów
}

\author{
Piotr Łętkowski \\ Oil and Gas Institute - National Research Institute
}

\begin{abstract}
Determination of the optimal number and placement of production wells is crucial for the effective depletion of the hydrocarbon reservoir. Due to the strongly non-linearity of the problem and the occurrence of multiple local minimums in the response function the non-gradient optimization methods in combination with reservoir simulations are most commonly used for its solution. However, it should be noted that most of the research works dedicated to this issue describe the process of placement optimization but not the number of drilling wells assuming that it was arbitrary set. This is partly due to the fact that known and used optimization methods operate on a fixed number of optimization parameters, therefore the number of production wells can not change during the optimization process. The paper is dedicated to the attempt to build an algorithm that allows simultaneous optimization of the number and position of production wells with respect to the discounted profit in a given period of operation. The basic optimization method in the presented algorithm is the Particle Swarm Optimization (PSO) - one of the most effective non-gradient optimization methods that belongs to the group of methods applying the swarm's intelligence. Taking into account the number of drilling wells in the optimization process means that the algorithm operates on a variable number of parameters. The objective algorithm starts optimization from an arbitrarily set number of producers, reducing it gradually. Efficiency tests conducted on the sample reservoir PUNQ-S3 indicated a satisfactory convergence of the proposed method. The computing program created implements the mechanisms of convergence enhancement by improving the boundary conditions for the optimization method. The minimum separation distance control between production wells was also introduced at the initial stage of optimization process. Although the algorithm is characterized by satisfactory convergence it would be advisable to improve it by using a hybrid method to increase its effectiveness in the local optimization phase and to introduce minimum well spacing during the entire optimization process.
\end{abstract}

Key words: optimization, reservoir simulation, swarm intelligence, particle swarm optimization, optimal number of wells, optimal well placement.

STRESZCZENIE: Określenie optymalnej liczby i położenia odwiertów eksploatacyjnych jest kluczowe dla efektywnej eksploatacji złoża węglowodorowego. Ze względu na silnie nieliniowy charakter problemu oraz występowanie w funkcji odpowiedzi wielokrotnych minimów lokalnych do jego rozwiązania najczęściej wykorzystywane są bezgradientowe metody optymalizacyjne w połączeniu z symulacjami złożowymi. Należy jednak zauważyć, że większość prac poświęconych temu zagadnieniu opisuje proces optymalizacji położenia, a nie liczby odwiertów, przyjmując, że jest ona dana arbitralnie. Wynika to po części z faktu, że znane i stosowane metody optymalizacyjne operują na stałej liczbie parametrów optymalizacyjnych, w związku z czym liczba odwiertów wydobywczych nie może zmieniać się w trakcie procesu optymalizacji. Artykuł jest poświęcony próbie zbudowania algorytmu umożliwiającego równoczesną optymalizację liczby i położenia odwiertów wydobywczych ze względu na zdyskontowany zysk w zadanym okresie eksploatacji. Podstawową metodą optymalizacyjną w prezentowanym algorytmie jest optymalizacja rojem cząstek (ang. PSO) - jedna z najbardziej efektywnych metod optymalizacji bezgradientowej, należąca do grupy metod wykorzystujących inteligencję roju. Próby efektywności metody przeprowadzone na przykładzie złoża testowego PUNQ-S3 wskazały na zadowalającą zbieżność zaproponowanej metody, dla której na początkowym etapie zastosowano kontrolę minimalnej odległości pomiędzy odwiertami. Jakkolwiek algorytm charakteryzuje się zadowalającą zbieżnością, to jednak wskazane byłoby jego udoskonalenie poprzez wykorzystanie metody hybrydowej w celu zwiększenia jego efektywności w fazie optymalizacji lokalnej oraz wprowadzenie kontroli odległości minimalnej w trakcie całego procesu optymalizacji.

Słowa kluczowe: optymalizacja, symulacje złożowe, inteligencja roju, optymalizacja rojem cząstek, optymalna liczba odwiertów, optymalne położenie odwiertów.

Corresponding author: P. Łętkowski, e-mail: piotr.letkowski@inig.pl

Article contributed to the Editor: 25.09.2019. Approved for publication: 04.12.2019 


\section{Introduction}

Determining the optimal number and placement of the production wells is critical for the effective operation of the hydrocarbon reservoir. The complex problem of optimal field development pattern is additionally complicated by the fact that hydrocarbon reservoir is characterized by in-homogeneous distributions of unknown or poorly recognized physical quantities which in combination with economic variables, reservoir fluid properties and well production controls determine the strongly non-linear nature of the issue.

An important help in the field development strategy are reservoir simulation numerical models that integrate all types of information describing the hydrocarbon reservoir. Although building a reliable simulation model is a difficult and time-consuming task however such a model can be successfully used to test various scenarios of reservoir performance. In particular, after setting up of detailed assumptions regarding the well production controls, it can be used to optimize position of production wells.

Because the answer domain of the thus formulated optimizing matter has many local minimums, the problem is most often solved using non-gradient optimization methods and numerical simulations. Various approaches to solving optimal wells spacing issue and optimization are found in the literature. In particular, genetic algorithms are used (Yeten et al., 2003; Güyagüler and Horne, 2004; Emerick et al., 2009; Lyons and Nasrabadi, 2013; Humphries and Haynes, 2015; Sampaio et al., 2015a; 2015b;), particle swarm optimization (Onwunalu and Durlofsky, 2010; Qihong et al., 2012; Nwankwor et al., 2013; Isebor et al., 2014), differential evolution (Awotunde, 2014; Atashnezhad et al., 2017), harmony search algorithm Afshari et al., 2011), the "imperialist competitive" algorithm (Naderi and Khamehchi, 2017), the bat-inspired algorithm (Keshavarz and Nader, 2016; Naderi, 2017; Łętkowski, 2018), covariance matrix adaption evolutionary strategy (Bouzarkouna et al., 2012; Feng et al., 2016), analytic and semi-analytical methods (Hazlett and Babu, 2005), machine learning (Nwachukwu et al., 2018), generalized pattern search (Humphries, 2014), directional search (Aliyev, 2011).

Among the evolutionary strategies the genetic algorithm is most often used and particle swarm optimization characterized by very good convergence. For that reason it has been used to solve numerous of optimization problems. It has also been used in this work as the basic method of optimization.

It is worth noting however, that most of works dedicated to this issue describe the process of infill well placement optimization rather then the number of wells, assuming that it is set arbitrarily. This is partially due to the fact that known and used optimization methods operate on a fixed number of optimization parameters, therefore the number of production wells can not change during the optimization process.
The subject of the presented work is an attempt to build an optimization algorithm for the selection of the number and placement of production wells with simultaneous optimization of the mentioned parameters (Ilamah and Ebere, 2017; Onwunalu, 2014; Isebor et al., 2015). As a measure of operational efficiency the NPV (net present value) was taken under consideration based on the analysis of discounted cash flows at a given rate of return.

The problem formulated in this way is an example of global optimization in the space of permitted locations and number of production wells.

\section{Problem identification}

The aim of the work was accomplished on the example of the following optimization problem: We are looking for such a number of vertical wells and their locations that for the given production well controls scheme the net present value (NPV) reach the maximum value with minimum number of production wells whilst the process of selecting of production wells number and their placements should proceed simultaneously.

Optimization of the engineered algorithm was carried out for a three-phase (oil, water, gas) PUNQ-S3 reservoir model (Barker et al., 2001; Floris et al., 2001). The simulation model of the PUNQ-S3 resevoir has been made available by Elf for testing purposes and is available on an Open Source basis. The model consists of 2660 blocks (mesh block $19 \times 28 \times 5$ ) of which 1761 blocks are active. This heterogeneous simulation model is described by the following petrophysical properties: (1) average porosity - $14.3 \%$, (2) average horizontal permeability $-278.8 \mathrm{mD}$, (3) average vertical permeability $-130.6 \mathrm{mD}$. The model includes a fault and two Carter-Tracy type active aquifers. The optimization process was carried out for the cumulative crude oil production in the field operated with a variable number of production wells over a period of 20 years.

There was Schlumberger's Blackoil Eclipse reservoir simulator used.

\section{Optimization algorithm}

\section{Particle Swarm Optimization}

In particle swarm optimizing the solutions so called "particles" work together in order to find the optimal solution. During the optimization process each particle while changing its position in the solution space marking up a velocity vector. This vector is modified using information about the search history for both a given particle and the remaining particles of the swarm. 
This way the searched solution space can be described using the following formulas:

position: $x_{t+1}^{i}=x_{t}^{i}+v_{t+1}^{i}$

velocity: $v_{t+1}^{i}=\omega v_{t}^{i}+c_{1} r_{1}\left(p_{t}^{i}-x_{t}^{i}\right)+c_{2} r_{2}\left(p_{t}^{g}-x_{t}^{i}\right)$

The position of the particle in the multidimensional space is modified in each iteration cycle according to the formula (1) through the velocity vector, (2). The velocity vector of the iteration step is a function of the previous value of the velocity vector, its position, the best solution found by the particle and the best global solution.

The remaining values appearing in formula (2) are defined below: $\omega$ - constant or variable coefficient of inertia,

$r_{1}, r_{2}$ - random numbers from the range $(0,1)$,

$c_{1}, c_{2}$-scaling parameters (variable or constant),

$p_{t}^{i}, p_{t}^{g}$ - respectively best i-th particle solution and best global solution.

The parameter $\omega$, called the inertia coefficient determines the effect of particle velocity in the previous iteration step on its current position. It is important for the algorithm convergence and in most applications occurs in the form dependent on the iteration number, e.g.:

$$
\omega=\omega_{\min }+\left(\omega_{\max }-\omega_{\min }\right) \times\left(1-\frac{k}{k_{\max }}\right)
$$

where:

$\omega_{\max }, \omega_{\min }-$ maximum and minimum value of parameter,

$k, k_{\max }-$ iteration and assumed number of iterations.

Values depend on the issue solving once usually assumed:

$$
\begin{aligned}
& \omega_{\max } \in(0.9,1.1) \\
& \omega_{\min } \in(0.1,0.5)
\end{aligned}
$$

According to the formulas listed above each swarm particle searches the space of solutions, modifying future location based on its current location, the best solution found so far and using the information on the best solution in the swarm of solutions. Scaling factors, $c_{1}, c_{2}$ allow to control the influence of velocity vector individual members on the solution. If the particle only uses information about the best swarm solution, $c_{1}=0$. For the particle that is self-looking for a solution but not taking into account the solutions found by other particles, $c_{2}=0$. Typically, coefficients take constant values are assumed. The post above the Particles Swarm Optimization is its classic form.

\section{Optimization variables representation}

The number and coordinates of production wells are the optimization variables for the analyzed problem. These coordinates are represented by dimensionless variables in the numerical model according to the following formulas:

$$
\begin{aligned}
& x=\operatorname{int}\left(a_{x} \xi+b_{x}+0.5\right) \\
& y=\operatorname{int}\left(a_{y} \xi+b_{y}+0.5\right)
\end{aligned}
$$

where: $x, y$ are production well coordinates in simulation model grid system, whereas $\xi, \eta$ are dimensionless coordinates respectively taking values from the range $(-1.0,1.0)$.

Factors $a_{x}, b_{x}, a_{y}, b_{y}$ been defined as follows:

$$
\begin{aligned}
& a_{x}=\frac{X_{\max }-X_{\min }}{2} \\
& b_{x}=\frac{X_{\max }+X_{\min }}{2} \\
& a_{y}=\frac{Y_{\max }-Y_{\min }}{2} \\
& b_{y}=\frac{Y_{\max }+Y_{\min }}{2}
\end{aligned}
$$

Where $X_{\min }=1, X_{\max }=19, Y_{\min }=1, Y_{\max }=28$ are simulation model grid numbering ranges.

The optimization process is conducted using dimensionless variables and conversion into real variables is performed in the process of generating simulator batch file.

A third variable was introduced to define the presence of the well. Depending on its value, the well is or is not included in the batch file generation process for the simulator.

\section{Optimization procedure}

In order to solve the set optimization problem, a numerical program implementing a modified Particle Swarm Optimization was deployed.

The details of applied solution are presented below:

1. Reading program operation parameters (wells control parameters, optimization method parameters, optimization parameters of the model, their variability ranges and definitions of controls size).

2. The drawing of solutions (group of models) for different combinations of production wells location and a given number of boreholes.

3. The objective function value determination for each of the particle swarm's model solutions. The NPV as objective function has been used:

$$
N P V=\left(\sum_{i=1}^{T_{\text {exp }}} \frac{Q_{o i} P_{o}-Q_{w i} P_{w}-O P E X}{(1+D)^{i}}-C A P E X\right)
$$

where:

$T$ - number of production years,

$Q_{o i}$ - cumulative crude oil production in i-year of production,

$P_{o}$ - the crude oil price for 1 cu.m., 
$Q_{w i}$ - cumulative formation water production in i-year of production,

$P_{w}$ - the formation water disposal cost for 1 cu.m.,

$O P E X, C A P E X$ - operational expenses and investments respectively,

$D$ - discount rate.

4. Update of local and global solutions. Due to the way the optimization problem was formulated, the basic optimization method was modified as follows:

a) the best particle solution is updated when the following conditions are met

$$
\begin{gathered}
N P V_{i}>N P V_{b e s t}^{i} \\
n p v_{i}>n p v_{\text {best }}^{i}
\end{gathered}
$$

b) similarly the best global solution is updated when the following condition is met

$$
\begin{gathered}
N P V_{\text {best }}^{i}>N P V_{\text {best }}^{\text {global }} \\
n p v_{\text {best }}^{i}>n p v_{\text {best }}^{\text {global }}
\end{gathered}
$$

where:

$N P V_{i}, N P V_{\text {best }}^{i}, N P V_{\text {best }}^{\text {global }}$ - value of objective function respectively for $i$-th particle, $i$-th particle best solution and best global solution,

$n p v_{i}, n p v_{\text {best }}^{i}, n p v_{\text {best }}^{\text {global }}$ - the above values per the appropriate number of wells.

5. Modification for each particles with the following modification in formula (2).

$$
\begin{aligned}
& c_{1}=2.5-2.0 \frac{k}{k_{\max }} \\
& c_{2}=0.5-2.0 \frac{k}{k_{\max }}
\end{aligned}
$$

To avoid premature convergence, a mutation technique was used as follows: A random number is generated for each well. Depending on its value, the well position is mutated by one model block in a random direction (see Fig. 1).

6. Return to point 3 .

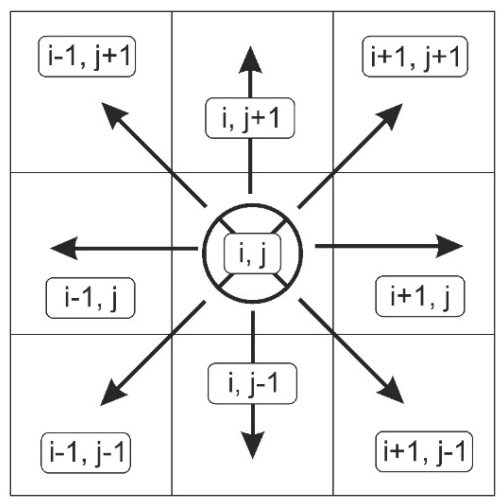

Fig. 1. Mutation principle adopted

Rys. 1. Zastosowany operator mutacji
The presented procedure is cycled until the stop condition is met, eg. achieving a certain number of iterations performed and/or achieving the assumed match between the average matching value in the swarm and the best match.

The algorithm was build in the way to exclude the user participation need from the optimization process. Therefore, the program has been equipped with analyzing modules for copying, moving and modifying batch files containing data and simulation results. After performing the necessary operations software application launches the reservoir simulator and after completing simulation it analyzes the obtained results.

\section{An optimization example for number and production wells locations}

\section{Optimization algorithm parameters}

The presented version of Particle Swarm Optimization method requires the several parameters assumptions. In particular, the number of swarm particles, $N=20$ and the initial number of wellbores, $N_{\text {winit }}=30$ were assumed.

In addition, the coefficient of inertia limits were established (see formula (3)),

$$
\omega_{\min }=0.4 \quad \omega_{\max }=0.9
$$

The proposed method also requires the assumption of swarm particles maximum movement velocity:

$$
v_{\max }^{i}=0.15
$$

Assuming NPV as an optimization criterion the following were defined in addition:

$P_{o}=\$ 629$ (the crude oil price for 1 cu.m.),

$P_{w}=\$ 32$ (the formation water disposal cost for 1 cu.m.),

$O P E X_{\text {well }}=5 \mathrm{mln} \$$ (the annual operation cost per production well),

$C A P E X_{\text {well }}=70 \mathrm{mln} \$$ (the total investment cost per well), $D=0.1$ (discount rate).

Independently, production well operation controls were defined and presented below:

- $\quad$ maximum well production rate, $W O P R_{M A X}=400 \frac{\mathrm{m}^{3}}{\mathrm{~d}}$

- $\quad$ maximum gas/oil ratio, $W G O R_{M A X}=300[-]$,

- economic oil production rate per well, $W O P R_{M I N}=30 \frac{\mathrm{m}^{3}}{\mathrm{~d}}$

- well production rate was controlled maintaining constant, $W B H P=150$ bars,

- exploitation time, $T_{\exp }=30$ years.

An additional mechanism was also introduced enabling well shut-in in case water/oil ratio or gas/oil ratio were exceeded. 


\section{Algorithm convergence}

In order to verify the efficiency of the algorithm, a convergence test was carried out for initial number of 30 production wells. In order to reduce the effect of randomness the optimization process was repeated 10 times and the results were averaged. As a result, NPV $=\$ 1.264$ billion was obtained for 6 production wells. The results of the convergence test are shown in Fig. 1. The algorithm is characterized by a satisfactory convergence meeting the end condition after 200 iterations (1000 simulations runs). Such a result should be considered very good taking into account the fact that 90 variables were optimized (30 production wells, having three coordinates each).

We observe a long period without improvement due to the difficulty in reducing the number of production wells while maximizing, what we can see on the Figures 3-4. Although in the initial optimization phase, both the number of wells, $N_{\text {well }}$ and the average profit per well, $n p v_{\text {best }}$ are significantly improved, followed by a long stagnation period of the algorithm.

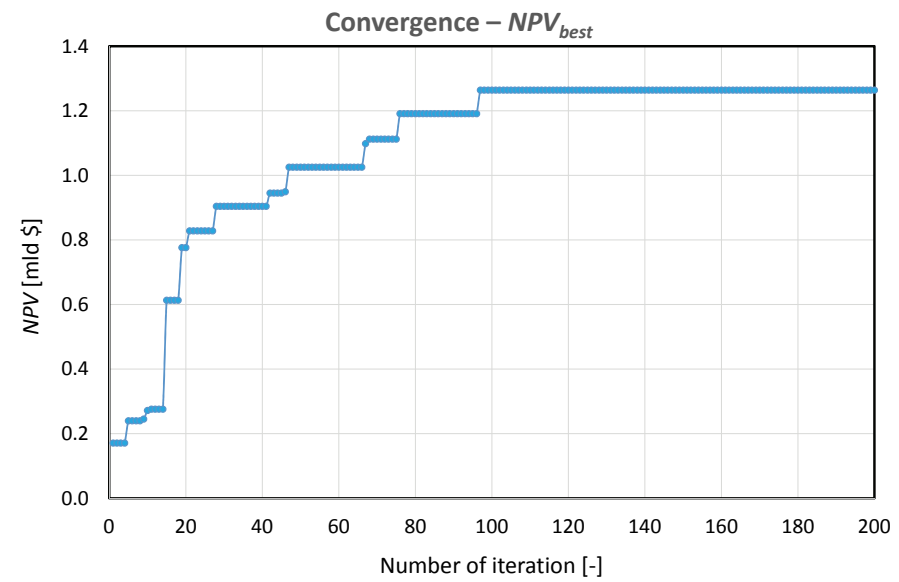

Fig. 2. Algorithm convergence. Net present value, $N P V_{\text {best }}$ Rys. 2. Zbieżność algorytmu. Wartość bieżąca netto, $N P V_{\text {best }}$

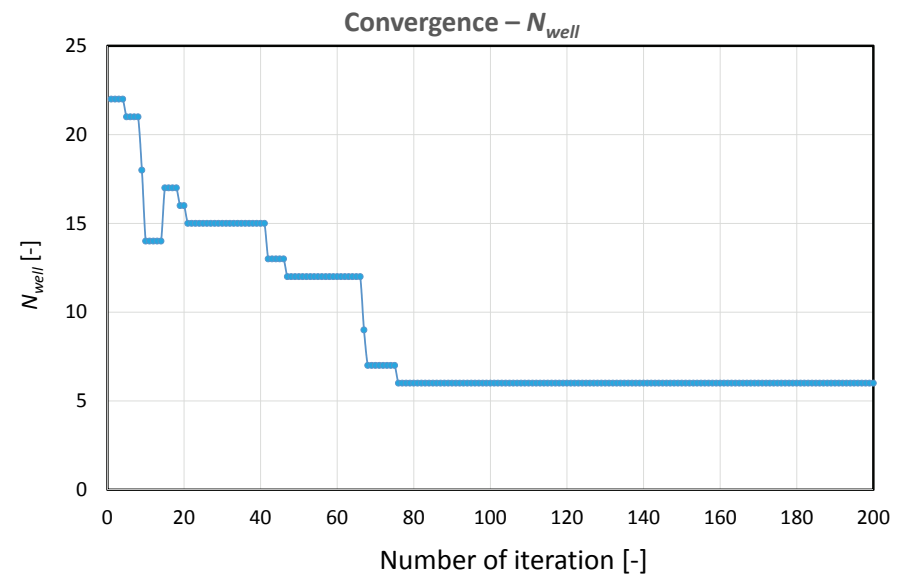

Fig. 3. Algorithm convergence. Numbers of wells, $N_{\text {well }}$ for global best solution

Rys. 3. Zbieżność algorytmu. Liczba odwiertów, $N_{\text {well }}$ dla najlepszego rozwiązania

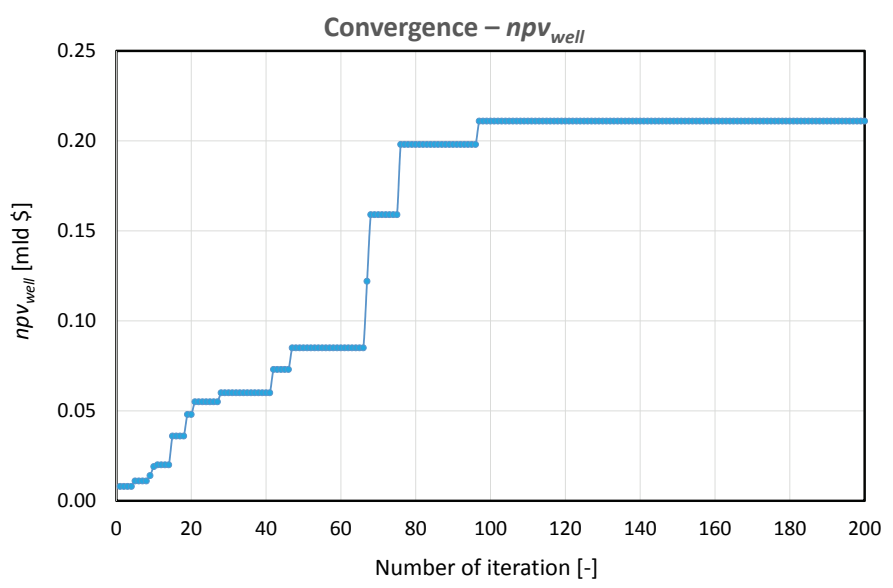

Fig. 4. Algorithm convergence. Average $N P V_{\text {best }}$ per well, $n p v_{\text {best }}$ for global best solution

Rys. 4. Zbieżność algorytmu. Średnia wartość bieżąca netto na odwiert, $n p v_{\text {best }}$ dla najlepszego rozwiązania

A change in the assumptions of the original optimization method caused problems with the effectiveness (convergence) of the method. Despite this, the proposed algorithm resulted in an sevenfold increase of $N P V_{\text {best }}$ over the initial value to the initial value and nearly a fourfold reduction of the number of wells, $N_{\text {well }}$. This means an 26-fold increase of $n p v_{\text {best }}$. The Fig. 5 shows the optimal wells placement obtained.

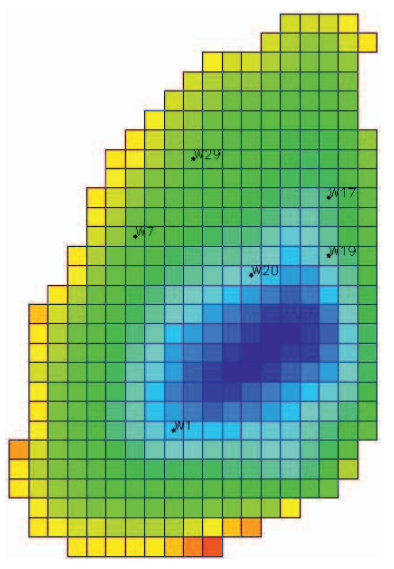

Fig. 5. Optimal wells placement Rys. 5. Optymalne rozmieszczenie odwiertów wydobywczych
The algorithm has placed the wells in the oil zone of the reservoir what is the solution consistent with the practice of reservoir engineering. This wells placement results from the imposed condition of the maximum gas/oil ratio on the one hand, and from the consideration of the cost of water utilization in the objective function.

\section{Summary}

The purpose of the work was an attempt to apply an automatic algorithm for determination of the number and location of production wells placement in order to optimize oil 
production in a given period of exploitation while the number and wells placement selection should proceed simultaneously. The problem was formulated as a conditional optimization by modifying the basic optimization method.

The scope of work included:

- optimization methods choice for the need of identified optimization problem;

- building an effective algorithm that enables the optimization process;

- numerical implementation of the created algorithm;

- the algorithm's operation simulation performance in order to find the optimal number and location of production wells for the selected sample formation.

As a result of the conducted simulations the possibility of using the selected heuristic technique to optimize the number and location of wells within assumed boundary conditions was confirmed.

Conducted simulation analysis allows to formulate the following conclusions and remarks:

- The basic optimization method selection turned out to be an significant problem. The first attempts carried out using genetic algorithms with variable chromosome length failed due to very poor algorithm convergence. Only the use of the Particles Swarm Optimization (PSO) allowed to obtain satisfactory algorithm efficiency.

- The conducted tests indicate the need to algorithm operate on dimensionless quantities. Their use significantly improves algorithm convergence despite the fact that the optimization parameters assume discrete values (the wellbores coordinates in the simulation model grid system).

- Some weakness of the stochastic sampling methods includes this particular optimization method is the need to determine the parameters of the algorithm that have significant impact on its convergence. The coefficient of inertia is particularly important, which was assumed as a linear function decreasing along with the iteration number increase. Also the remaining coefficient of the formula (2) has been addicted to number of iteration.

- It is noticed the lack of efficiency of the created algorithm in the local optimization stage. This is manifested by the algorithm's disability to improve the result after the initial and significant value increase. This is a feature of the base optimization method assumed, unfortunately. In the case of continuation the presented subject it would be advisable to improve the existing algorithm with an effective local optimization mechanism activated in the case of a longer lack of improvement in the result.

This paper was written on the basis of the statutory work entitled: Optimization algorithm for a variable number of parameters on the example of selection of the number and position of production wells - the work of Oil and Gas Institute - National Research Institute was commissioned by the Ministry of Science and Higher Education; order number: 0022/KZ/2018, archive number: DK-4100-0022/2018.

\section{References}

Afshari S., Aminshahidy B., Pishvaie M.R., 2011. Application of an improved harmony search algorithm in well placement optimization using streamline simulation. Journal of Petroleum Science and Engineering, 78(3-4): 664-678.

Al Dossary M.A., Nasrabadi H., 2016. Well placement optimization using imperialist competitive algorithm. Journal of Petroleum Science and Engineering, 147: 237-248.

Aliyev E., 2011. Use of Hybrid Approaches and Metaoptimization for Well Placement Problems. Thesis, Stanford University.

Atashnezhad A., Cedola A., Hareland G., 2017. An empirical model to estimate a critical stimulation design parameter using drilling data. Society of Petroleum Engineers. DOI: 10.2118/185741-MS.

Awotunde A., 2014. On the joint optimization of well placement and control. Society of Petroleum Engineers. DOI: 10.2118/172206-MS.

Barker W.J., Cuypers M., Holden L., 2001. Quantifying uncertainty in production forecasts: another look at the PUNQ-S3 problem. SPE Journal, 6: 433-441.

Bouzarkouna Z., Ding D., Auger A., 2012. Well placement optimization with the covariance matrix adaptation evolution strategy and meta-models. Comput. Geosci., 16: 75-92.

Emerick A., Silva E., Messer B., Almeida L., Szwarcman D., Pacheco M., Vellasco M., 2009. Well placement optimization using a genetic algorithm with nonlinear constraints. Society of Petroleum Engineers. DOI: 10.2118/118808-MS.

Feng Q., Chen H., Wang X., Wang S., Wang Z., Yang Y., Bing S., 2016. Well control optimization considering formation damage caused by suspended particles in injected water. Journal of Natural Gas Science and Engineering, 35: 21-32.

Feng Q., Zhang J., Zhang X., Hu A., 2012. Optimizing well placement in a coalbed methane reservoir using the particle swarm optimization algorithm. International Journal of Coal Geology, 104: $34-45$.

Floris F.J.T., Bush M.D., Cuypers M., Roggero F., Syversveen A.-R., 2001. Methods for quantifying the uncertainty of production forecasts: a comparative study. Pet. Geosci., 7: S87-S96.

Güyagüler B., Horne R.N., 2004. Uncertainty assessment of well-placement optimization. SPE Reserv. Eval. Eng., 7(1): 24-32.

Hazlett R.D., Babu D.K., 2005. Optimal well placement in heterogeneous reservoirs via semi-analytic modeling. SPE Journal, 10(3): 286-296.

Humphries T., Haynes R., 2015. Joint optimization of well placement and control for nonconventional well types. Journal of Petroleum Science and Engineering, 126: 242-253.

Humphries T., Haynes R., James L., 2014. Simultaneous and sequential approaches to joint optimization of well placement and control. Comput. Geosci., 18: 433-448.

Ilamah O., Ebere M., 2017. Fast Tracking Field Development Optimization With Nature Inspired Heuristics. Society of Petroleum Engineers. DOI: 10.2118/189173-MS.

Isebor O.J., Ciaurri, D.E., Durlofsky, L., 2014. Generalized field-development optimization With derivative-free procedures. Society of Petroleum Engineers. DOI: 10.2118/163631-PA.

Keshavarz M., Naderi M., 2016. Drilling rate of penetration prediction and optimization using response surface methodology and bat algorithm. J. Nat. Gas. Sci. Eng., 31: 829-841. 
Lyons J., Nasrabadi H., 2013. Well placement optimization under time-dependent uncertainty using an ensemble Kalman filter and a genetic algorithm. Journal of Petroleum Science and Engineering, 109: 70-79.

Łętkowski P., 2018. Semi-Automatic Algorithm for Optimal Production Well Placement. Nafta-Gaz, 8: 598-605. DOI: 10. 18668 /NG.2018.08.05.

Naderi M., Khamehchi E., 2017. Well placement optimization using metaheuristic bat algorithm. Journal of Petroleum Science and Engineering, 150: 348-354.

Nwachukwu A., Jeong H., Pyrcz M., Lake L.W., 2018. Fast evaluation of well placements in heterogeneous reservoir models using machine learning. Journal of Petroleum Science and Engineering, 163: 463-475.

Nwankwor E., Nagar A., Reid D., 2013. Hybrid differential evolution and particle swarm optimization for optimal well placement. Comput. Geosci., 17: 1-20.

Onwunalu J., Durlofsky L., 2010. Application of a particle swarm optimization algorithm for determining optimum well location and type. Comput. Geosci., 14: 183-198.

Onwunalu J., Durlofsky L., 2014. A New Well-Pattern-Optimization Procedure for Large-Scale Field Development. Society of Petroleum Engineers. DOI: 10.2118/124364-PA.
Sampaio M., Barreto C., Schiozer D., 2015a. Assisted optimization method for com- parison between conventional and intelligent producers considering uncertainties. Journal of Petroleum Science and Engineering, 133: 268-279.

Sampaio M., Gildin E., Schiozer D., 2015b. Short-term and long-term optimizations for reservoir management with intelligent wells. Society of Petroleum Engineers. DOI: 10.2118/177255-MS.

Yeten B., Durlofsky L., Aziz K., 2003. Optimization of nonconventional well type, location, and trajectory. Society of Petroleum Engineers. DOI: 10.2118/86880-PA.

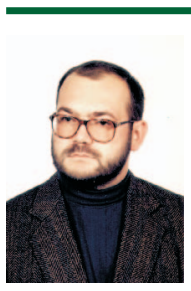

Dr inż. Piotr ŁĘTKOWSKI

Adiunkt w Zakładzie Symulacji Złóż Węglowodorów i Podziemnych Magazynów Gazu

Instytut Nafty i Gazu - Państwowy Instytut Badawczy ul. Lubicz $25 \mathrm{~A}$

31-503 Kraków

E-mail: piotr.letkowski@inig.pl

\section{OFERTA BADAWCZA ZAKŁADU SYMULACJI ZŁÓŻ WĘGLOWODORÓW I PMG}

- sporządzanie ilościowych charakterystyk ztóż naftowych (konstruowanie statycznych modeli złożowych);

- analizy geostatystyczne dla potrzeb projektowania modeli ztóż naftowych, w tym PMG i wielofazowych obliczeń wolumetrycznych;

- konstruowanie dynamicznych symulacyjnych modeli ztóż i ich kalibracja;

- wszechstronne badania symulacyine dla potrzeb:

» weryfikacji zasobów płynów złożowych,

» metod wspomagania wydobycia (zattaczanie gazu lub wody, procesy WAG, procesy wypierania mieszającego, oddziaływanie chemiczne),

» optymalizacji rozwiercania i udostępniania ztóż,

» prognozowania ztożowych i hydraulicznych (w tym termalnych) charakterystyk odwiertów (w szczególności poziomych) dla celów optymalnego ich projektowania,

» sekwestracji $\mathrm{CO}_{2}$;

projektowanie, realizacjai wdrażanie systemów baz danych dla potrzeb górnictwa naftowego.

Kierownik: dr Wiesław Szott Adres: ul. Armii Krajowej 3, 38-400 Krosno Telefon: 134368941 w. 5104 Faks: 134367971 E- mail: wieslaw.szott@inig.pl

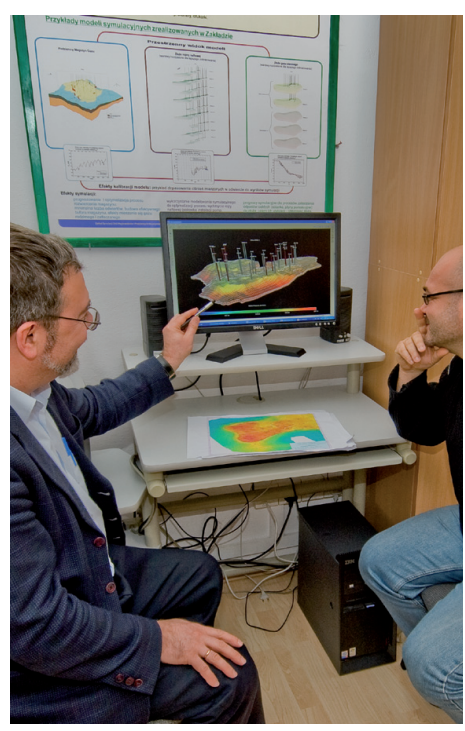

INSTYTUT NAFTY I GAZU - Państwowy Instytut Badawczy 